\title{
Identification of speakers' voices in open trials of corruption cases: acoustic phonetic analysis
}

\author{
Tengku Silvana Sinar ${ }^{1}$, Nurlela $^{2}$, T. Thyrhaya Zein ${ }^{3}$ \\ \{tengkusilvana@usu.ac.id ${ }^{1}$,nurlelamajrul@usu.ac.id ${ }^{2}$, t.thyrhaya@usu.ac.id ${ }^{3}$ \} \\ Universitas Sumatera Utara, Medan, Indonesia
}

\begin{abstract}
This study is about the identification of speakers' voices on a recording of forensic corruption open trials case for defendants held at the Medan District Court. The purpose of the study is to find out the functional features of duration, intensity, pitch, and frequency of the speakers' voices. The use of qualitative research methods was applied and Praat software was used for collecting and processing the data of speech sounds. The results of the study showed that the level of differentiation in voices delivered by judges, prosecutor, and witnesses, and the functional features of duration, intensity, pitch, and frequency of the speakers' voices in oral language used in trial corruption cases vary to one the other.
\end{abstract}

Keywords: Acoustic phonetics, corruption case, forensic linguistic, praat

\section{Introduction}

Circular Number: 04 of 2012 from the Supreme Court, with Number: 08 / BUA.6 / HS / $\mathrm{SP} / \mathrm{VIII} / 2012$ is concerned with recording of proceedings stating that the trial at the court of first instance must be accompanied by audiovisual [1].

Following the relevant statement of Circular Number from the Supreme Court and as stated in CHAPTER II item 6 through 15 presented previously, (furthermore read Law Number 30 of 2002 [2]) about a large duty, authority and obligation of KPK (Corruption Eradication Commission) to the state, its role in combating corruption never stops from time to time especially as big and wide country like Indonesia (coverage from the island of Sabang to Merauke) they commit that Indonesia must be free from corruptors.

Therefore, the participation of the whole society and academicians in state and private universities is needed to solve the problem of the trial of corruption cases both in the forms of teaching and research in accordance with the dedication to the nation. This research was conducted to explore the lingual data used by people suspected of gratification at the trial, specifically, the objective of this research is to identify the indication and symptoms in the use of corrupt languages in terms of frequency, duration and intensity of voices.

Since the aspects in question are functionally interrelated with the approach used in this study, therefore forensic linguistics in a trial of a corruption case was combined with the experimental approach to measure the prosodic characteristic of sounds. The experimental approach was applied to detect and identify the acoustic of the voice symptoms with Praat software program. Experimental approach is a phonetic study using an accurate measuring device ([3], [4]) either in tracing the pitch movement or measuring the acoustic characteristics. 
Frequency determines the pitch that called intonation (rise and fall) and variety in the series of pitch of utterance in a language such as the height and low of the pitch of a sound. The duration is a period of time needed to realize a segment measured in millisecond. If the segment is in the form of sentence, that period of time is usually called tempo. The intensity is the loudness or sonority of a sound which based on the width of air wave.

Why should be this research collaborate phonetics as a micro linguistic study with other interdisciplinary sciences that is forensic study. The factor relates to the world of the Forensic linguistic study covers three aspects, i.e. (1) language in legal products, (2) language in courts, and (3) language as evidence; focusing the lingual data on written and oral language. Language of law is able to be utilized as research data. One reason for the existence of this fact that the academician mostly carried out lectures by providing the students with general knowledge in the context of forensic. This means that in the lecturing process the lecturers employ significances of research due to make a new contribution to analyse the language used by participants involved in corruption cases during the trial. The electronic device are used by the clerk of the court for audio (visual) text into written language in conducting the research methods. The recording has been done from the beginning of the trial, until the judge's decision. Therefore, the recording can be evidence in the trial, as well as a documentary for clerks. If, at some point a person or group wants to review the results of the trials, the clerks can show the document back to the recording. During the open trial of TIPIKOR, they used Indonesian language as a communication tool used in the courtroom due to its the linguistic policy that Indonesia has its own rules and philosophies.

The support in Krishna's study [5] states that technological sophistication is developed to record modes of crime in Indonesia. One of them is a crime through mobile phones or cellphones. Meanwhile, according to Shavers and Bair [6] in almost every case, the user data of individuals such as short message service (SMS), call history, MMS, media (images/video/ sound files), application data, chat messages, browser history GPS data, and more will be where certain physical memory partitions are located on a NAND or NOR chip.

Shanty [7] furthermore mentioned that the variety of legal languages must pay attention to the scientific study of language structure and rules of standard Indonesian. Therefore, legal language does not prioritize language style, but prioritizes language certainty. Previous studies in corruption case was investigated by Subagja [8] in his dissertation, Sanksi pidana mati terhadap pelaku tindak pidana korupsi. He explained that the sanctions for the death penalty for perpetrators of corruption to be one of the last efforts to prevent and eradicate corruption.

Syamsudin [9] compares the ratio of law enforcement corruption in Indonesia that the sanctioning of corruption is still be punished with criminal penalties and not the maximum and minimum impressed, while in China shows that sanctions or punishment of the perpetrators of corruption carried out with the heaviest of which the maximum penalty or capital punishment that sanction the death penalty for criminals is the last option in Indonesia although the comparison with China has done the maximum punishment for criminals. The comparison of both punishments in the two countries is very interesting in term of language study. This is because until now the territory of the Unitary Republic of Indonesia has had 652 regional languages according to the Ministry of Education and Culture [10].

Ramiyanto [11] in his paper mentions that the method of interpretation involved constitutes the language or grammatical interpretation, historical interpretation of the legislation, systematic interpretation, interpretation of society (teleological / sociological), comparative interpretation, futuristic interpretation (anticipatory), interpretation restrictive, extensive interpretation, authentic interpretation, interdisciplinary interpretation, and multidisciplinary interpretation. The interpretations reinforced by Usman Pakaya [12] are to 
identify the context of the text that can be understood comprehensively, such as content, form, purpose, and participants.

An acoustic phonetic investigation is carried out intensively to find a pattern that is typical of the speaker, be it a judge, prosecutor, lawyer, suspect, or expert witness [13]. Meanwhile, Kristianto [14] mentions that phonetic analysis makes it possible to uncover the truth of texts in detail, to trace and discover the truth of the text creator. Suryani and Darmayanti [15] said that currently, the measurement of acoustic features have developed a computer program such as computerized speech research environment (CRSE), and praat.

These previous studies provide contribution to this research, focusing on the identification voices and with respect to the schematic structure types that are found in the court discourse, the following stages are necessarily to occur in the court trials [16].

Table 1. Stages necessarily occuring in court trials.

\begin{tabular}{|c|c|}
\hline Stage One: & Trial remains opened and it's opened to the public \\
\hline Stage Two: & The Judge ordered to bring the defendant to the front of the trial \\
\hline Stage Three: & $\begin{array}{l}\text { Judge's question to the Defendant regarding his condition and willingness to be } \\
\text { examined before the trial }\end{array}$ \\
\hline Stage Four: & The judge invites the witness and public prosecutor \\
\hline Stage Five: & The judge orders the public prosecutor to present witnesses \\
\hline Stage Six: & Judge's inspection on witnesses' bio data \\
\hline Stage Seven: & Witness oath \\
\hline Stage Eight: & $\begin{array}{l}\text { Judge asks to the legal counsel. Stage nine: The judge invited legal counsel to ask } \\
\text { questions }\end{array}$ \\
\hline Stage Nine: & The judge invited legal counsel to ask questions \\
\hline Stage Ten: & $\begin{array}{l}\text { Examination of the defendant and the judge determine whether there are parties } \\
\text { who are objected }\end{array}$ \\
\hline Stage Eleven: & Judge's decision \\
\hline
\end{tabular}

One important question to answer here is of how are the speaker's voices provide significant contribution for scientific reason of forensic study. My short answer to this study is that it is closely related to the fact that the acoustic study have the potentials to occur by the participants to achieve particular goals at the courts. In this case, it was found that the language of law is the language of rules and regulations aimed at realizing order and justice, to defend public interests and personal interests in society. However, to agree with Ferlianus Gulo in [17] saying that statutory language is part of the modern Indonesian, then the consumer should have bright monosemantics and qualified Indonesian aesthetics.

\section{Research Method}

This study uses qualitative research method with the following procedures and methods. For analyzing the sound, Praat software is applied in the method with the following procedures. The recorded sound first edited and then opened in the software for further analysis. There are procedures of data collection and data processing techniques as described below:

(i) Accessing the recorded sound of the trial.

(ii) Editing the sound file for enhancing the quality and reducing the noise in the sound.

(iii) Converting the sound file from MP3 to .wav before opening the file in Praat Object 
(iv) Opening the .wav file in Praat Object.

(v) Marking boundary for each sentences in the file.

(vi) Converting the Stereo sound to Mono with Convert feature in Praat Object.

(vii) Applying Annotate feature for marking each words in the sentences. For helping the researcher finding the opening and closing of a phoneme, the Spectogram feature is enabled.

(viii) The sentence with marked words is then moved to the Praat Picture with applying the Draw feature in Praat Object.

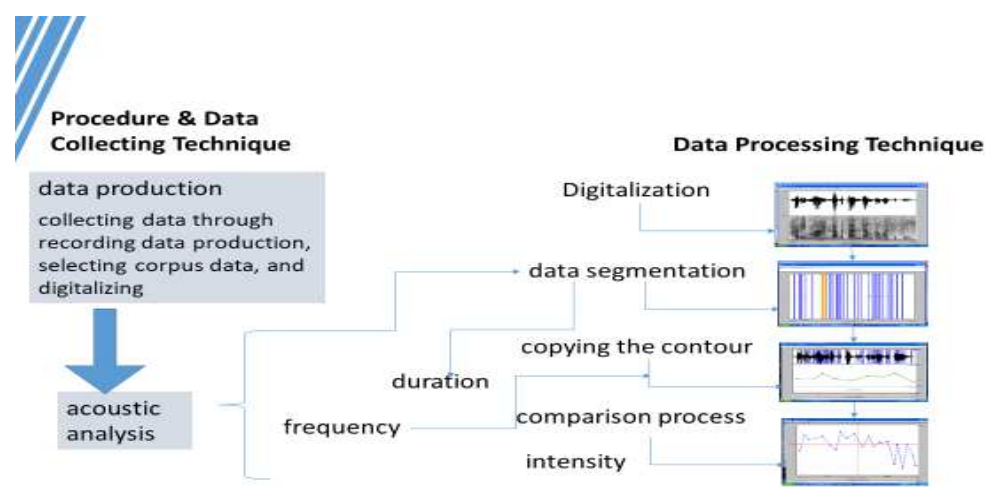

Fig. 1. Procedur, data collecting technique and data processing techniques.

In data analysing techniques, the following steps have been applied.

(i) Applying View \& Edit feature in Praat Object for obtaining the total Duration value of a sentence.

(ii) Applying Annotate - To TextGrid... feature in Praat Object for obtaining each words Duration value.

(iii) Applying Get minimum intensity feature for obtaining the minimum Intensity value and Get maximun intensity feature for obtaining the maximum Intensity value.

(iv) Applying Pitch listing feature for obtaining the Pitch value on the beginning and the end of a sentence.

(v) Displaying the picture of Duration, Intensity, and Pitch in Praat Picture.

Drawing the objects in Praat display is purposed for inserting the picture in any writing documents during the research. For distinguishing each phonetics features in the picture, the researcher applies black color to indicate for Duration, red color to indicate for Intensity, and blue color to indicate for Pitch.

With this step, using an audio tape recorder, which can be used in the conversion technique from audio (visual) is transcribed into written text.

The results of the transfer of spoken language into a form of transcript to written language, the court can also use the trial transcript application, to verify the use of language in the trial, so that court clerks, judges, prosecutors can re-read things that happened during the trial. This document can also be used by the linguists to act as forensic witnesses at the trial and also as a data analyzer examining the language that occurs in the trials in micro linguistics as well as macro linguistics. 


\section{Results and Discussion}

Recording of the trial of a corruption case held in the Medan TIPIKOR court, found an outcome in the form of linguistics that have the potential to occur in discourse in general or in courtroom discourse in particular. This finding signifies a language phenomena, which is used, so that communication that is intertwined in the trial has one direction and purpose. The findings discussed in this study are as follows.

However, the focus here is on how particular existing functional features have motivated particular intensity, duration and frequency to occur. The technical or operational terms that are used in this study have in fact signalled how potential they are for particular emotional state to appear in the texts. Let me clarify this by exemplification.

Let me start from the functional characteristics that have enabled the identification of voices to gain its prominence over the other voices. An inference can be drawn from the data that the occurrences of the type within the confines or in support of the occurrences of the Prosecutors' demands type in particular has motivated the occurrences of nervous. Observe the sample sounds fragment below.

The beginning of the trial, the clerk calls the defendants, Maringan Situmorang and Saiful Azhar. In this trial, the witness was heard, namely Mangapul Butar-butar as the witness of the defendant Maringan Situmorang. In the first case the defendant Situmorang and Syaiful Azhar began to enter the courtroom. Then the judge addressed the defendant's speech, "Do you feel healthy today?"

It should be noted that the occurrences of the statement of the prosecutor's question to the witness Maringan Situmorang, starting with the sentence [can the witness explain].

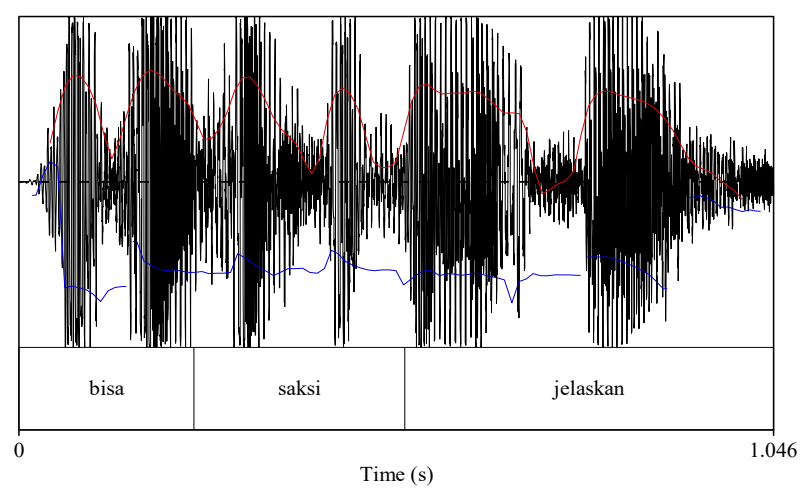

Fig. 2. Duration, intensity, and pitch of attorney speech.

The feature notated is the prosecutor's demand to the witness Maringan Situmorang, starting with the sentence [bisa saksi jelaskan], has its duration 1.0 second, the word [bisa] has its duration of 0.2 second, [saksi] 0.3 second, and [jelaskan] 0.5 second. The intensity [bisa saksi jelaskan], varies from basic intensity $72.9 \mathrm{~dB}$ [jelaskan], final intensity $92.0 \mathrm{~dB}$ on the word[bisa]. The Pitch pattern of [bisa saksi jelaskan] decreases on the word [bisa], starting from $204.4 \mathrm{~Hz}$ to the final utterance $191.5 \mathrm{~Hz}$. 
Table 2. Attorney speech.

\begin{tabular}{|c|c|c|c|c|c|}
\hline $\begin{array}{l}\text { Prosecutors' } \\
\text { demands }\end{array}$ & Duration & Total Duration & $\begin{array}{c}\text { The word } \\
\text { bisa }\end{array}$ & $\begin{array}{c}\text { The word } \\
\text { saksi }\end{array}$ & $\begin{array}{l}\text { The word } \\
\text { jelaskan }\end{array}$ \\
\hline $\begin{array}{l}\text { bisa saksi } \\
\text { jelaskan }\end{array}$ & & 1.046 seconds & 0.242 seconds & 0.292 seconds & $\begin{array}{c}0.511 \\
\text { seconds }\end{array}$ \\
\hline $\begin{array}{l}\text { can the } \\
\text { witness } \\
\text { explain }\end{array}$ & $\begin{array}{l}\text { Intensity } \\
\text { Pitch }\end{array}$ & $\begin{array}{r}\text { Basic } \\
72 . \\
\mathrm{F} \\
204\end{array}$ & $\begin{array}{l}\text { ensity } \\
\mathrm{dB} \\
\mathrm{y} \\
\mathrm{Hz}\end{array}$ & $\begin{array}{r}\text { Final int } \\
92.05 \\
\text { En } \\
191.51\end{array}$ & \\
\hline
\end{tabular}

Witness answers Maringan Situmorang who has begun to be nervous about the judge's question [many of the packages do not remember].

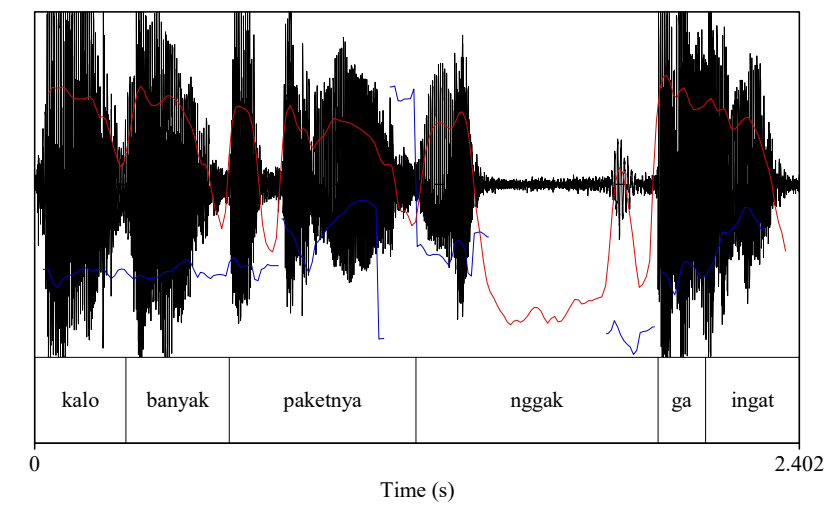

Fig. 3. Duration, intensity, and pitch of witness speech.

If the speaker talks about something which is related to the who aspect in the real world and the real world is human (would typically be so), animate (would typically be so) and concrete (would typically be so) and is concerned with practical/observable activities or the like, the first potential type to occur would generally be the judge's speech questioned the witness Maringan Situmorang [total projects].

Table 3. Witness speech.

\begin{tabular}{|c|c|c|c|c|c|c|c|c|}
\hline $\begin{array}{l}\text { Witness } \\
\text { Speeches }\end{array}$ & Duration & $\begin{array}{c}\text { Total } \\
\text { Duration }\end{array}$ & $\begin{array}{l}\text { The } \\
\text { word } \\
\text { kalo }\end{array}$ & $\begin{array}{c}\text { The word } \\
\text { banyak }\end{array}$ & $\begin{array}{l}\text { The word } \\
\text { paketnya }\end{array}$ & $\begin{array}{c}\text { The } \\
\text { word } \\
\text { nggak }\end{array}$ & $\begin{array}{c}\text { The } \\
\text { word ga }\end{array}$ & $\begin{array}{l}\text { The } \\
\text { word } \\
\text { Ingat }\end{array}$ \\
\hline $\begin{array}{c}\text { Kalo } \\
\text { banyak } \\
\text { paketnya } \\
\text { nggak ga } \\
\text { ingat } \\
\text { In case of } \\
\text { many of } \\
\text { packages, } \\
\text { do not } \\
\text { remember }\end{array}$ & $\begin{array}{l}\text { Intensity } \\
\text { Pitch }\end{array}$ & $\begin{array}{c}2.402 \\
\text { seconds }\end{array}$ & $\begin{array}{c}0.268 \\
\text { seconds } \\
\text { Basic intensity } \\
55.58 \mathrm{~dB} \\
\text { Early } \\
149.052 \mathrm{~Hz}\end{array}$ & $\begin{array}{c}0.324 \\
\text { seconds }\end{array}$ & $\begin{array}{c}0.586 \\
\text { seconds }\end{array}$ & $\begin{array}{r}0.760 \\
\text { seconds } \\
\text { Final i } \\
91.1 \\
\mathrm{E} \\
180.8\end{array}$ & $\begin{array}{l}\text { 0.150 } \\
\text { seconds } \\
\text { nsity } \\
\text { B. } \\
\text { Hz. }\end{array}$ & $\begin{array}{c}0.150 \\
\text { seconds }\end{array}$ \\
\hline
\end{tabular}




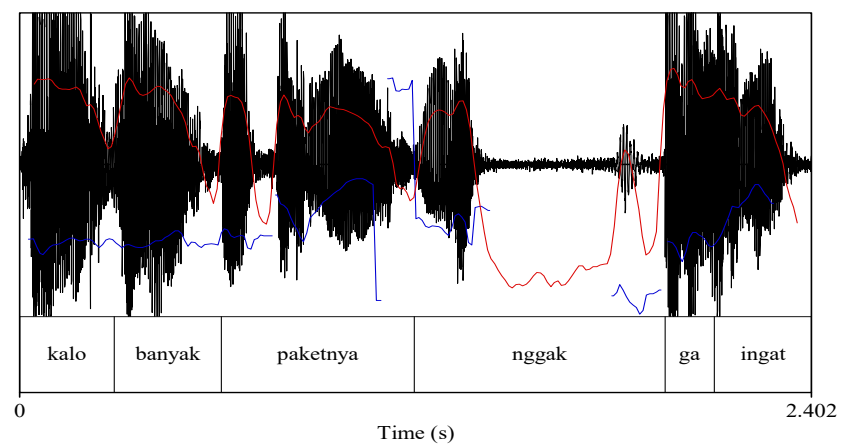

Fig. 4. Duration, intensity, and pitch of judge speech

Secondly the feature of Witness's duration when he begun to be nervous to answer the judge's question (he said he does not remember how many of the packages). There is a duration of long pause between enggak and ga. This shows the possibility of the occurrence of nervous to repeat the words 'enggak' dan 'ga'. The occurrence [kalo banyak paketnya ga gak ingat] has its duration 2.4 second (the word [kalo] 0.26 second, the word [banyak] 0.3 second, [paketnya] 0.6 second, in the word [nggak], 0.7 second, at [ga] 0.2 second and [ingat] 0.2 second).

The intensity when uttering [kalo banyak paketnya ga gak ingat], shows that basically the intensity of $55.58 \mathrm{~dB}$ to the final intensity $91.11 \mathrm{~dB}$. Pitch pattern in the utterance [kalo banyak paketnya enggak.. ga ingat] is fluctuated from $149.1 \mathrm{~Hz}$ to $180.8 \mathrm{~Hz}$.

Furthermore, the in the production of sounds in words and phrases further remarks are made. Firstly concerning the prosecutor's demand to the witness of MSitumorang, starting with the utterance [bisa saksi jelaskan], has its duration 1.0 second, the word [bisa] has its duration of 0.2 second, [saksi] 0.3 second, and [jelaskan] 0.5 second. This may also be observed in the intensity of [bisa saksi jelaskan] that varies from basic intensity $72.92 \mathrm{~dB}$ [jelaskan] to final intensity $92.05 \mathrm{~dB}$ on the word [bisa]. When [bisa saksi jelaskan] is said, the Pitch pattern decreases on the word [bisa], starting from $204.4 \mathrm{~Hz}$ to the final utterance 191.5 Hz.

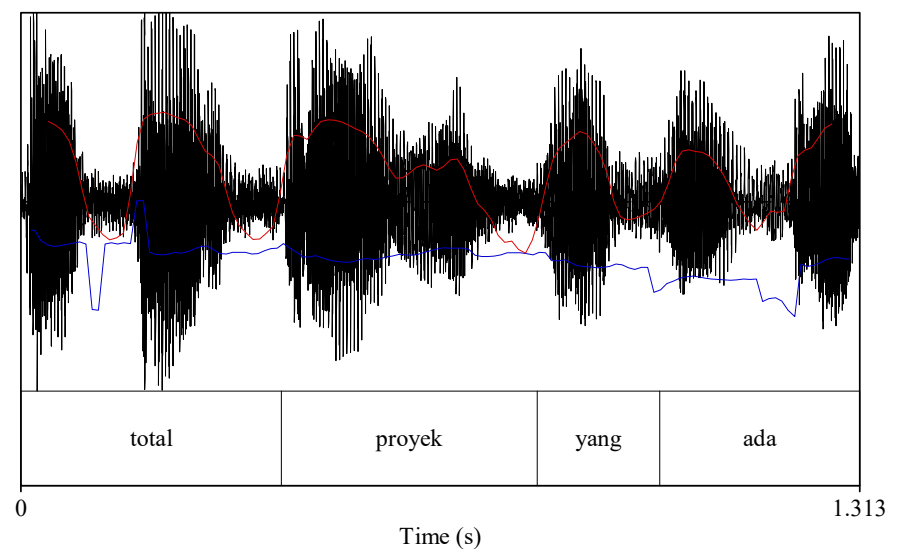

Fig. 5. Judge's speech total proyek yang ada 
Table 4. Judge's speech total proyek yang ada.

\begin{tabular}{|c|c|c|c|c|c|c|}
\hline $\begin{array}{c}\text { Judge } \\
\text { Speeches }\end{array}$ & Duration & $\begin{array}{c}\text { Total } \\
\text { Duration }\end{array}$ & $\begin{array}{c}\text { The word } \\
\text { total }\end{array}$ & $\begin{array}{c}\text { The word } \\
\text { proyek }\end{array}$ & $\begin{array}{c}\text { The word } \\
\text { yang }\end{array}$ & $\begin{array}{c}\text { The word } \\
\text { ada }\end{array}$ \\
\hline $\begin{array}{l}\text { total } \\
\text { proyek }\end{array}$ & & $\begin{array}{c}1.313 \\
\text { seconds }\end{array}$ & $\begin{array}{c}0.407 \\
\text { seconds }\end{array}$ & $\begin{array}{c}0.401 \\
\text { seconds }\end{array}$ & $\begin{array}{c}0.191 \\
\text { seconds }\end{array}$ & $\begin{array}{c}0.312 \\
\text { seconds. }\end{array}$ \\
\hline yang ada & & \multicolumn{2}{|c|}{$\begin{array}{c}\text { Basic intensity } \\
68.79 \mathrm{~dB}\end{array}$} & \multicolumn{3}{|c|}{$\begin{array}{c}\text { Final intensity } \\
87.09 \mathrm{~dB} .\end{array}$} \\
\hline $\begin{array}{c}\text { total } \\
\text { projects }\end{array}$ & Pitch & Early & $\begin{array}{l}\mathrm{y} \\
\mathrm{Hz}\end{array}$ & & End & \\
\hline
\end{tabular}

The third case shows the Judge's flat duration 1.3 second when uttering [total proyek yang ada], [total] 0.4 second, the word [proyek] 0.4 second, [yang] 0.9 second, [ada] 0.3 second. In the production of approximately utterance [total proyek yang ada], the speaker way of producing them show the following the basic intensity $68.79 \mathrm{~dB}$ [proyek] to the intensity final $87.09 \mathrm{~dB}$ [ada]. On the other hand, when uttering [total proyek yang ada], it receives the pitch pattern that slightly decreases from $194.8 \mathrm{~Hz}$ to $174.39 \mathrm{~Hz}$.

Speech question to clarify by the judge to witness Maringan Situmorang [why was the money not handed over to pokja].

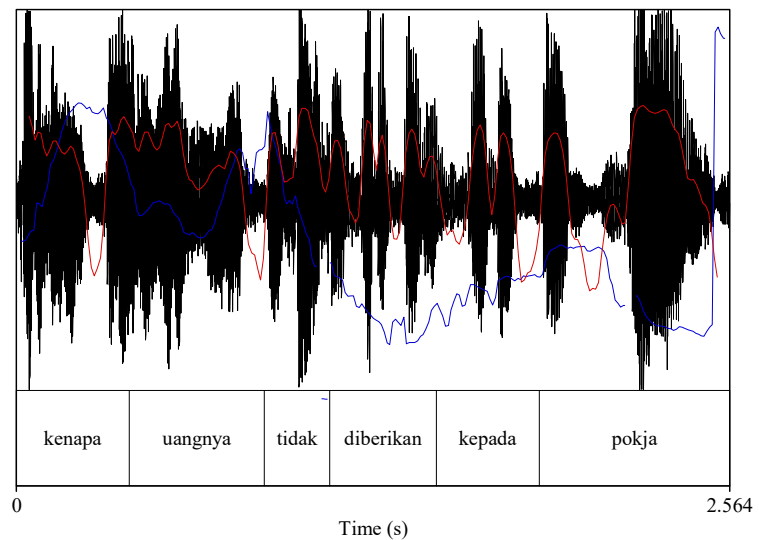

Fig. 6. Duration, intensity, and pitch of judge speech to witnesses

Speech question to clarify by the judge to witness MaringanSitumorang [total projects].

Table 4. Judge speeches.

\begin{tabular}{|c|c|c|c|c|c|c|c|c|}
\hline $\begin{array}{c}\text { Judge } \\
\text { Speeches }\end{array}$ & Duration & $\begin{array}{c}\text { Total } \\
\text { Duration }\end{array}$ & kenapa & $\begin{array}{l}\text { Uang } \\
\text { nya }\end{array}$ & tidak & diberikan & kepada & pokja \\
\hline $\begin{array}{c}\text { total proyek } \\
\text { yang ada }\end{array}$ & & $\begin{array}{c}2.564 \\
\text { seconds }\end{array}$ & $\begin{array}{c}0.404 \\
\text { seconds }\end{array}$ & $\begin{array}{c}0.486 \\
\text { seconds }\end{array}$ & $\begin{array}{c}0.235 \\
\text { seconds }\end{array}$ & $\begin{array}{c}0.383 \\
\text { seconds }\end{array}$ & $\begin{array}{c}0.371 \\
\text { seconds }\end{array}$ & $\begin{array}{c}0.685 \\
\text { seconds }\end{array}$ \\
\hline $\begin{array}{l}\text { total } \\
\text { projects }\end{array}$ & $\begin{array}{l}\text { Intensity } \\
\text { Pitch }\end{array}$ & $\begin{array}{r}\text { Basic i } \\
65.0 \\
\mathrm{Ea} \\
191 .\end{array}$ & $\begin{array}{l}\text { ensity } \\
\mathrm{dB} \\
\mathrm{y} \\
\mathrm{Hz}\end{array}$ & & & $\begin{array}{c}\text { inal intensi } \\
88.12 \mathrm{~dB} . \\
\text { End } \\
330.29 \mathrm{~Hz} .\end{array}$ & & \\
\hline
\end{tabular}


Speech about the testimony of witness Mangapul Butar-butar on the question of the prosecutor / public prosecutor. The Sentang Bridge construction project in Batubara District is worth IDR 31 billion. Witness statement, the money was given to the Oka Arya Regent.

The fourth case when the Judge uttering [kenapa uangnya tidak diberikan kepada pokja], the duration shows 2.6 second ([kenapa] 0.4 second, [uangnya] 0.4 second, [tidak] 0.2 second, [diberikan] 0.4 second, [kepada] 0.3 second, [pokja] 0.7 second). The emotion of Judge results the increase of basic intensity $65.0 \mathrm{~dB}$, to $88.12 \mathrm{~dB}$ at the last syllable of the word [pokja]. The frequency significantly increases, and the pitch pattern [kenapa uangnya tidak diberikan kepada pokja] is fluctuated from $191.9 \mathrm{~Hz}$ to $330.3 \mathrm{~Hz}$.

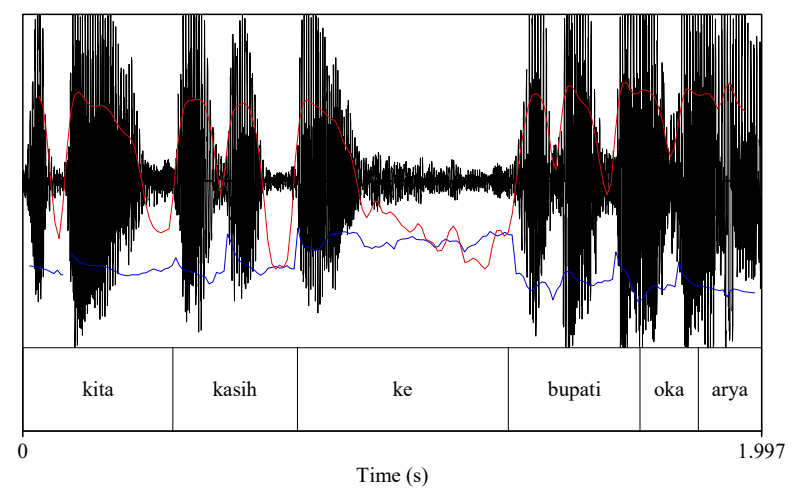

Fig. 7. Duration, intensity, and pitch of witness speech

Table 6. Witness speeches.

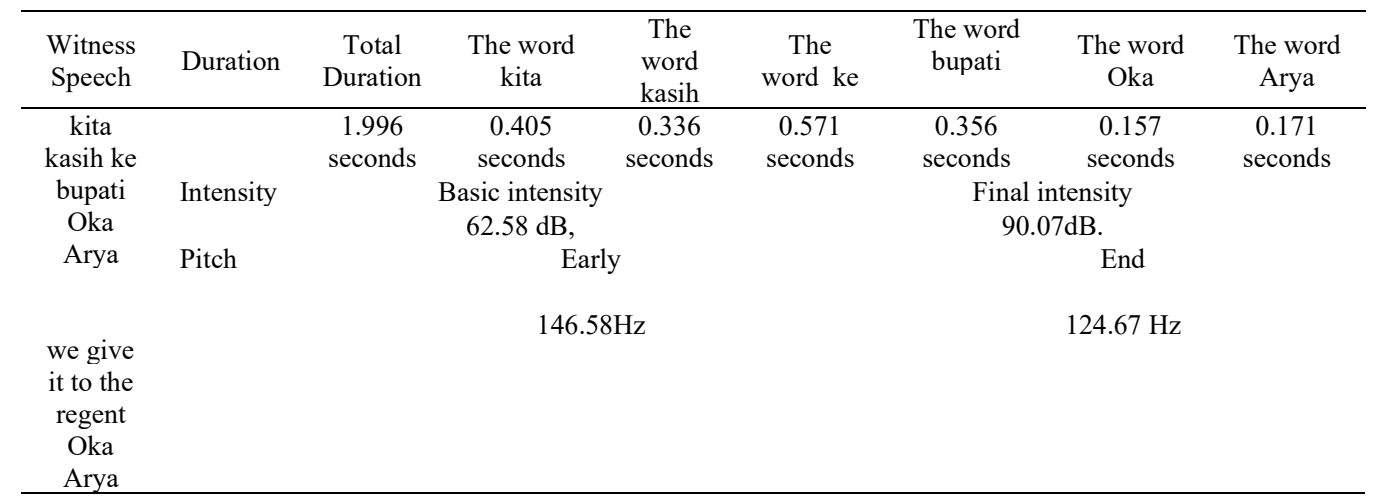

The occurrence of witness utterance of [kita kasih ke bupati oka arya] shows a long duration and pause 1.9 second, ([kita] duration 0.4 second, [kasih] duration 0.3 second, [ke] duration 0.5 second, [bupati] 0.3 second, [oka] 0.15 second, [arya] 0.17 second) as to show panic. This is an important factor on the possibility of the occurrence of bribery as the intensity [kita kasih ke bupati oka arya] raise from normal intensity $62.58 \mathrm{~dB}$ at the word [ke] to $90.07 \mathrm{~dB}$ ] at the address [bupati]. The pitch pattern [kita kasih ke bupati oka arya] decrease slightly from $146.58 \mathrm{~Hz}$ to $124.92 \mathrm{~Hz}$ at the end of uttering the address [bupati].

Speech for the sentence [give the regent ten percent] to the regent, in which this sentence was repeated by the public prosecutor. 


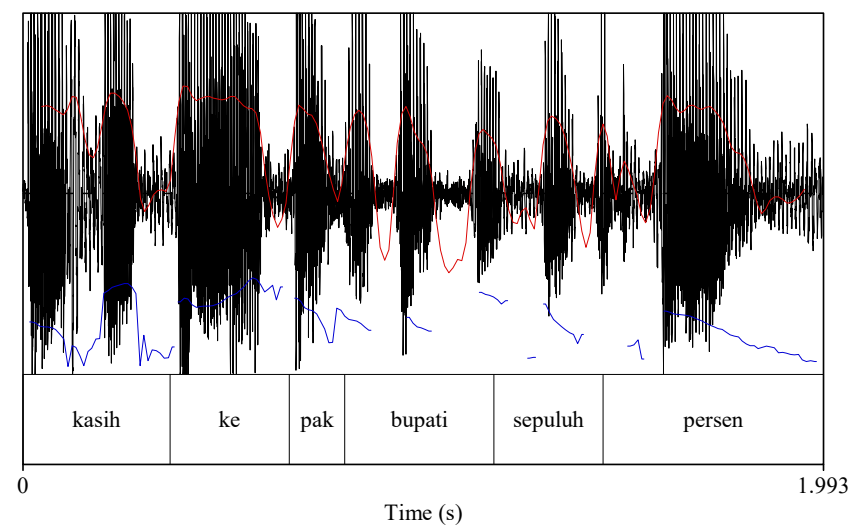

Fig. 8. Duration, intensity, and pitch of attorney speech

The utterance of Majesty Judge [kasih ke pak bupati sepuluh persen] has its duration of 1.9 second, [kasih] duration 0.3 second, The feature that may be notated is the occurrence of a pause in the word [ke] duration 0.2 second, [pak] duration 0.1 second, [bupati] duration 0.3 second, [sepuluh] duration 0.2 second [persen] duration 0.5 second. The intensity in the utterance [kasih ke pak bupati sepuluh persen], is $64.7 \mathrm{~dB}$, in the final word $90.3 \mathrm{~dB}$ and the basic intensity is on the word [bupati], whereas the final intensity in the word [ke].

The Pitch on the utterance [kasih ke pak bupati sepuluh persen] is stressed from the initial of $119.6 \mathrm{~Hz}$ to the final sentence to become $89.92 \mathrm{~Hz}$. The Majesty judge repeats witness's address OK Arya using synonym 'bupati' in order to clarify that 10 percentage of the commission had been given to head of district The judge's speech is forwarded to the witness [kalo gitu tendernya gak fair dong], have its duration as 1.5 second, in the word [kalo] 0.2 second, in the word [gitu] 0.3 second, in the word[tendernya] 0.3 second, in the word[gak] 0.2 second, in the word[fair] 0.1 second, and the word[dong] 0.2 second. The final intensity in the utterance [kalogitutendernyagak fair dong]is 87.7 dbin the word [tendernya], and the basic intensity is $69.03 \mathrm{~dB}$ in the word [gitu]. Meanwhile the frequency in uttering this [kalo gitu tendernya gak fair dong]is fluctuated. The fluctuation starts at the initial utterance which is 122.6 Hz and ends at the final utterance as $123.7 \mathrm{~Hz}$.

Table 7. Duration of attorney's speech.

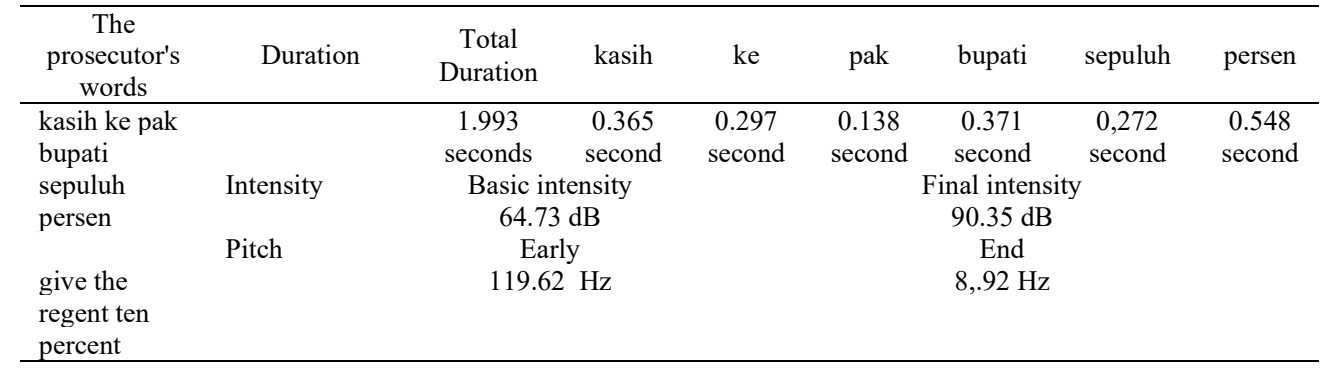

Speech of the judge's question to reinforce [ten percent to regents] 


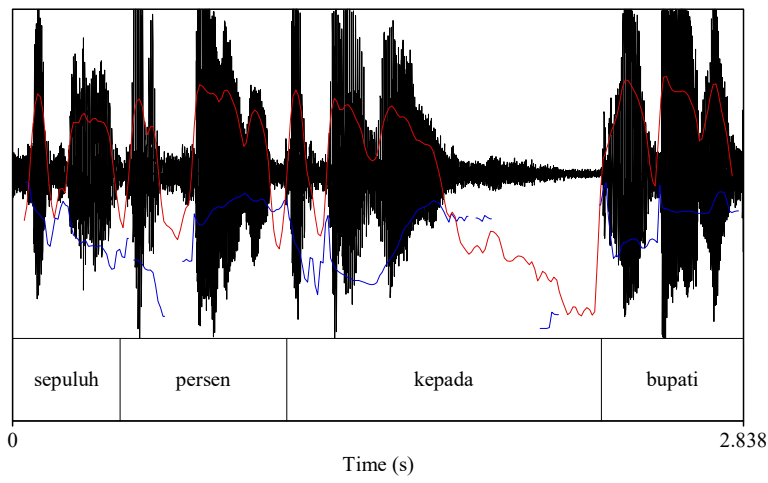

Fig. 9. Duration, intensity, and pitch of judge speech

Table 8. Duration of of judge speeches.

\begin{tabular}{|c|c|c|c|c|c|c|}
\hline $\begin{array}{c}\text { Speech of } \\
\text { Judge }\end{array}$ & Duration & $\begin{array}{c}\text { Total } \\
\text { Duration } \\
\end{array}$ & sepuluh & persen & kepada & bupati \\
\hline $\begin{array}{c}\text { sepuluh } \\
\text { persen }\end{array}$ & & $\begin{array}{c}2,838 \\
\text { seconds }\end{array}$ & $\begin{array}{c}0,416 \\
\text { seconds }\end{array}$ & $\begin{array}{c}0,647 \\
\text { seconds }\end{array}$ & $\begin{array}{c}1,221 \\
\text { seconds }\end{array}$ & $\begin{array}{c}0.552 \\
\text { seconds }\end{array}$ \\
\hline $\begin{array}{l}\text { kepada } \\
\text { bupati }\end{array}$ & $\begin{array}{l}\text { Intensity } \\
\text { Pitch }\end{array}$ & \multicolumn{2}{|c|}{$\begin{array}{c}\text { Basic intensity } \\
54,32 \mathrm{~dB}\end{array}$} & \multicolumn{3}{|c|}{$\begin{array}{c}\text { Final intensity } \\
90,07 \mathrm{~dB} \\
\text { End } \\
185,02 \mathrm{~Hz}\end{array}$} \\
\hline $\begin{array}{l}\text { ten percent } \\
\text { to regents }\end{array}$ & & & & & & \\
\hline
\end{tabular}

The Judge's statement [sepuluh persen kepada bupati] has its duration 2.8 second, at the point [sepuluh], the duration 0,4 second, at the word [persen] 0,6 second, [kepada] 1,2 second, [bupati] 0,5 second.

Intensity of the Judge's utterances who is in doubt to the witness statement [sepuluh persen kepada bupati], basic intensity $54.32 \mathrm{~dB}$ in the word [kepada], final intensity $90.07 \mathrm{~dB}$ in the word [bupati]. The same question is asked by the Majesty Judge. The pitch pattern on the utterance [sepuluh persen kepada bupati] has been fluctuated that starting with $208.24 \mathrm{~Hz}$ to $185.02 \mathrm{~Hz}$.

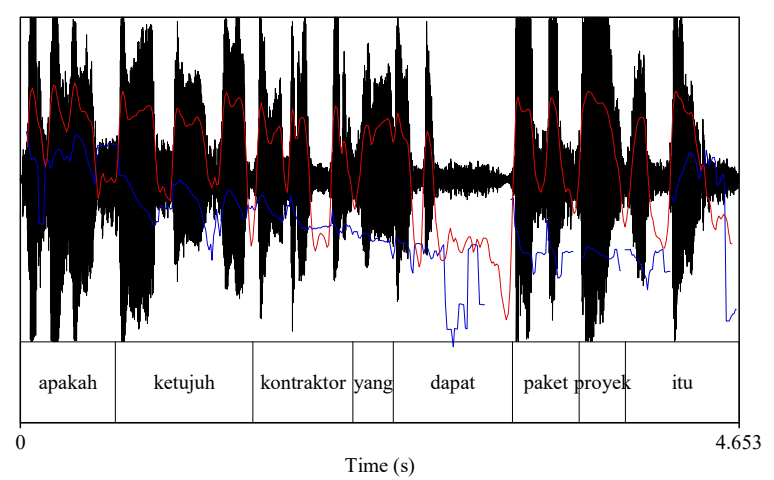

Fig. 10. Duration, intensity, and pitch of judge question 
Figure 8 showed the judge's question to the witness [Are the seven contractors to package the project], the pitch pattern of the utterances [apakah ketujuh kontraktor yang dapat paket proyek itu] decreases from $254.9 \mathrm{~Hz}$ to $107.2 \mathrm{~Hz}$.

Table 9. Duration of judge question speech.

\begin{tabular}{|c|c|c|c|c|c|c|c|c|c|c|}
\hline Judge's question & Duration & $\begin{array}{c}\text { Total } \\
\text { Duration }\end{array}$ & $\begin{array}{l}\text { Apa- } \\
\text { kah }\end{array}$ & $\begin{array}{l}\text { ke- } \\
\text { tujuh }\end{array}$ & $\begin{array}{c}\text { kontrak } \\
\text { tor }\end{array}$ & yang & dapat & paket & proyek & itu \\
\hline \multirow{5}{*}{$\begin{array}{l}\text { Apakah ketujuh } \\
\text { kontraktor yang dapat } \\
\text { paket proyek itu } \\
\text { Are the seven } \\
\text { contractors win the } \\
\text { the project package }\end{array}$} & & $\begin{array}{c}4.652 \\
\text { sec }\end{array}$ & $\begin{array}{c}0.614 \\
\text { sec }\end{array}$ & $\begin{array}{c}0.889 \\
\text { sec }\end{array}$ & $\begin{array}{c}0.650 \\
\text { sec }\end{array}$ & $\begin{array}{c}0.261 \\
\text { sec }\end{array}$ & $\begin{array}{c}0.769 \\
\text { sec }\end{array}$ & $\begin{array}{c}0.434 \\
\text { sec }\end{array}$ & $\begin{array}{c}0.299 \\
\text { sec }\end{array}$ & $\begin{array}{c}0.734 \\
\text { sec }\end{array}$ \\
\hline & Intensity & \multicolumn{4}{|c|}{ Basic intensity } & \multicolumn{5}{|c|}{ Final intensity } \\
\hline & & \multicolumn{4}{|c|}{$54.32 \mathrm{~dB}$} & \multicolumn{5}{|c|}{$90.09 \mathrm{~dB}$} \\
\hline & Pitch & \multicolumn{4}{|c|}{ Early } & \multicolumn{5}{|c|}{ End } \\
\hline & & \multicolumn{4}{|c|}{$254.903 \mathrm{~Hz}$} & \multicolumn{5}{|c|}{ 107.271 Hz } \\
\hline
\end{tabular}

The judge's speech clarified his question [Required to provide fee]. Another feature that may be notated is the occurrence of a stable emotion of judge with the duration 3.3 second in uttering [diwajibkan untuk memberikan fee], [diwajibkan] duration 1.5 second, [untuk] 0.6 second, [memberikan] 0.9 second, [fee] 0.28 second. The Judge pronounce this utterance with basic intensity $60.75 \mathrm{~dB}$ to final intensity $90.26 \mathrm{~dB}$ [diwajibkan]. The Pitch pattern receives a pitch level of $152.39 \mathrm{~Hz}$ change into to higher level $193.31 \mathrm{~Hz}$ at the end of the utterance.

The unit for the frequency of sound is estimated per second. the difference in frequency of each sound depends on the source that produces the particular sound, while the height of the wave can determine the intensity of the sound at the same frequency. Thus, if there are sounds that have the same frequency of joining, then the amplitude for the combined sound will increase and the intensity will also increase.

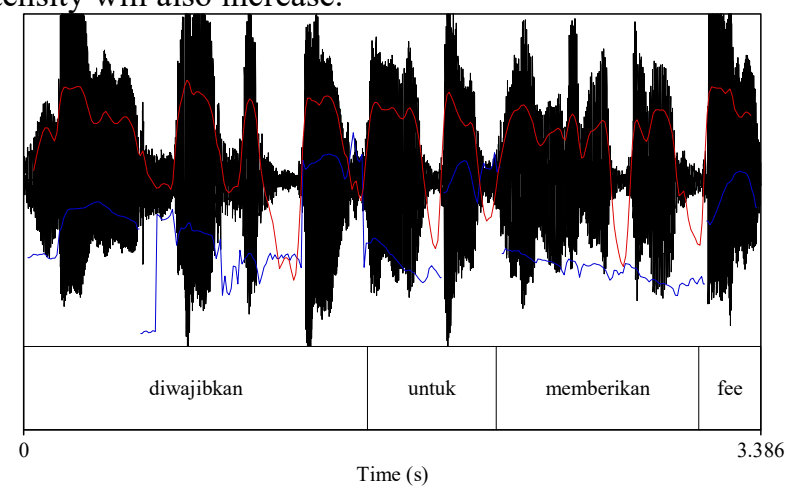

Fig. 11. Duration, intensity, and pitch of judge speech

Table 10. Duration of judge speeches.

\begin{tabular}{|c|c|c|c|c|c|c|}
\hline Judge speech & Duration & $\begin{array}{c}\text { Total } \\
\text { Duration }\end{array}$ & $\begin{array}{l}\text { The word } \\
\text { diwajibkan }\end{array}$ & $\begin{array}{c}\text { The word } \\
\text { untuk }\end{array}$ & $\begin{array}{l}\text { The word } \\
\text { memberikan }\end{array}$ & $\begin{array}{c}\text { The word } \\
\text { fee }\end{array}$ \\
\hline $\begin{array}{c}\text { Diwajibkan untuk } \\
\text { memberikan fee }\end{array}$ & & $\begin{array}{c}3.386 \\
\text { seconds }\end{array}$ & $\begin{array}{c}1.578 \\
\text { seconds }\end{array}$ & $\begin{array}{c}0.592 \\
\text { seconds }\end{array}$ & $\begin{array}{c}0.929 \\
\text { seconds }\end{array}$ & $\begin{array}{c}0.284 \\
\text { seconds }\end{array}$ \\
\hline $\begin{array}{l}\text { Required to provide } \\
\text { fee }\end{array}$ & $\begin{array}{l}\text { Intensity } \\
\text { Pitch }\end{array}$ & $\begin{array}{r}\text { Basi } \\
60 \\
152\end{array}$ & $\begin{array}{l}\text { tensity } \\
\mathrm{dB} \\
\mathrm{dy} \mathrm{Hz}\end{array}$ & & $\begin{array}{c}\text { Final intensity } \\
90.26 \mathrm{~dB} \\
\text { End } \\
193.310 \mathrm{~Hz}\end{array}$ & \\
\hline
\end{tabular}




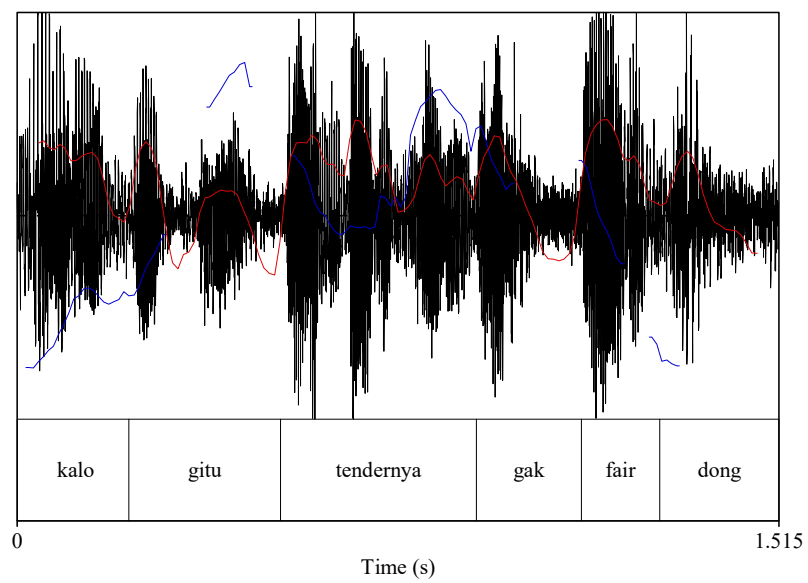

Fig. 12. The Judge utterance [kalo gitu tenderny agak fair dong]

The Judge utterance [kalo gitu tenderny agak fair dong], have its duration as 1.515 second, in the word [kalo] 0.222 second, in the word [gitu] 0.301 second, in the word[tendernya] 0.389 second, in the word [gak] 0.209 second, in the word [fair] 0.155 second, and the word [dong] 0.236 second. The final intensity in the utterance [kalogitutendernyagak fair dong] is 87.72 dbin the word [tendernya], and the basic intensity is $69.03 \mathrm{~dB}$ in the word [gitu]. Meanwhile the frequency in uttering this [kalo gitu tendernya gak fair dong] is fluctuated. The fluctuation starts at the initial utterance which is $122.64 \mathrm{~Hz}$ and ends at the final utterance as $123.77 \mathrm{~Hz}$.

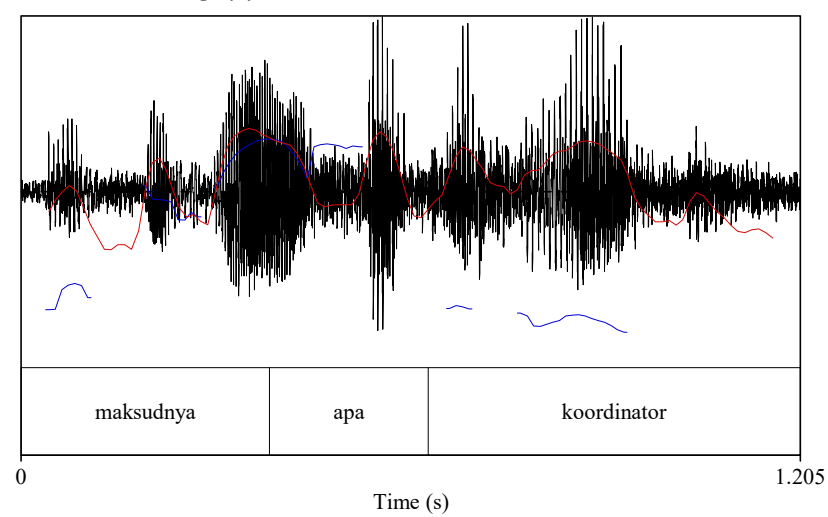

Fig. 13. The judge's question [maksudnya apa koordinator]

When the Judge asks question to the witness [maksudnya apa koordinator], the total duration is 1.2 second, whereas in the word [maksudnya] turns down to 0.383 second, the word [apa] 0.2 second, and [koordinator] rises to 0.575 second. He tries to make sure the intention of witness to mention [maksudnya apa koordinator], resulting the intensities at the final of $84.31 \mathrm{~dB}$ on the word [apa] and the basic intensity is $67.3 \mathrm{~dB}$ in the word [maksudnya]. Meanwhile, the frequency starts with $124.7 \mathrm{~Hz}$ in the initial utterance, rises in the middle of the utterance and ends with $107.6 \mathrm{~Hz}$ at the final utterance. 


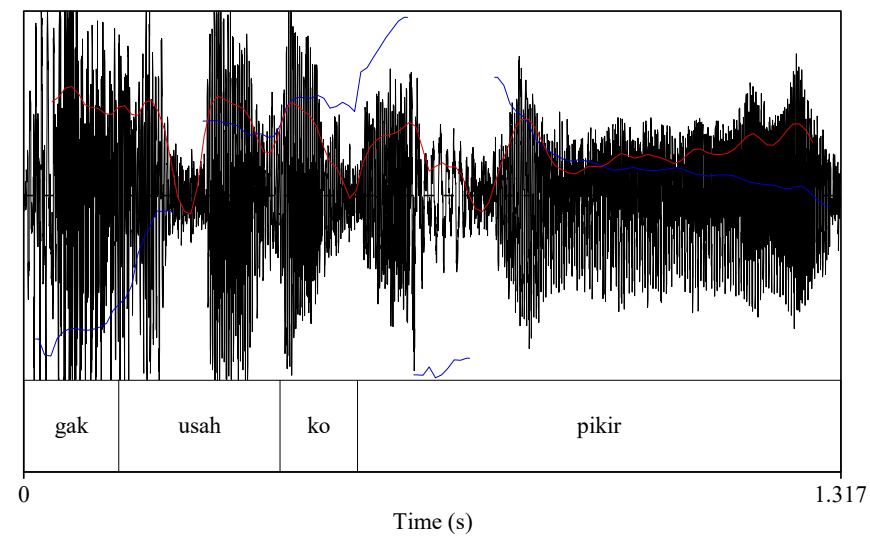

Fig. 14. The Judge's utterance [gak usah ko pikir]

The Judge's utterance [gak usah ko pikir], has the total duration of 1.317 second with the word [gak] 0.152 second, the word [usah] 0.260 secondand the word [ko] 0.125 second, [pikir] 0.779 second. The Judge's utterance [gakusahkopikir], is produced with standard intensity $90.07 \mathrm{~dB}$ on [gak], $72.67 \mathrm{~dB}$ on [usah]. In addition, the frequency of Judge's voice in the utterance [gakusahkopikir], becomes rise to $110.41 \mathrm{~Hz}$ in the middle and at the end of the sentence $207.65 \mathrm{~Hz}$.

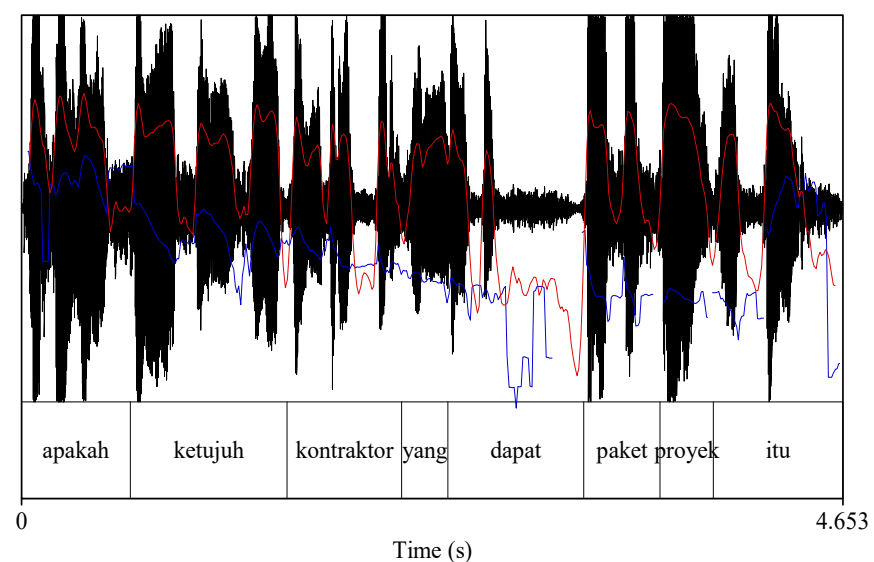

Fig. 15. The utterance [apakah ketujuh kontraktor yang dapat paket proyek itu]

The utterance [apakah ketujuh kontraktor yang dapat paket proyek itu] has its duration 4.6 second. at the word [apakah] duration 0.6 second, at the word [ketujuh] 0.889 second, at the word [kontraktor] 0.650 second, at the word [yang] 0.2 second, kata [dapat] 0.7 second, at the word [paket] 0.4 second, at the word [proyek] 0.3 second, the word [itu] 0.7 second.

The intensity of the Judge's utterance has been fluctuated on the utterance [apakah ketujuh kontraktor yang dapat paket proyek itu], the basic intensity $54,32 \mathrm{~dB}$, to the final intensity 90,09 dB. This basic intensity uttered at the word [dapat], and the final intensity at the word [itu]. The pitch pattern points at the utterances [apakah ketujuh kontraktor yang dapat paket proyek itu] decreases from $254,9 \mathrm{~Hz}$ to $107,2 \mathrm{~Hz}$. 


\section{Conclusions}

The results of the research on the functional features of identification of verbal discourse on the trial of corruption cases in the TIPIKOR court in the case of the defendant Maringan Situmorang and Syaiful Azhar have found at the level of duration, intensity, pitch and the frequencies from highest to the lowest level when the judges and prosecutor questioned the witnesses. It is proven through the Praat software, which is successful to examine sounds in the form of acoustic phonetics.

Furthermore, the dominance that occurred in the trial was a question from the prosecutor against the witness. Speech of the judge who has the sharpness in hearing witness statements, during the trial, and, also with questions submitted to witnesses, with a sentence of ten percent to the Regent. Read the results of the sentence from the judge with his firmness stating ten percent to the Regent with the duration below.

Table 11. Duration of the sentence from the judge.

\begin{tabular}{cccc}
\hline Sepuluh & persen & Kepada & Bupati \\
\hline 0.416 seconds & 0.647 seconds & 1.221 seconds & 0.552 seconds \\
\hline
\end{tabular}

The high duration found from the analysis results indicates that there is a prioritizing attitude directed at the Regent as the highest official in the district. Furthermore, the Regent is also the official who signs the contract of the project in development, in accordance with the opening of the 1945 Constitution, in the fourth paragraph, with the aim of promoting public welfare.

The need for Praat software in identifying votes in court proceedings can finally be a necessity for further research. Technology development is happening now, making the software had been developed to a high specification, and will be the tools used. Hopefully, the technology invented by man not to commit the crime, but to human needs, so that human activities more easily, and, easy to reach their goals.

Likewise, in the corruption case that occurred in Indonesia that never ended. Both of human behavior betrayed the mandate of the ideals of the Indonesian people, to advance public welfare. This is written in the preamble to the 1945 constitution, the fourth paragraph to the thirteenth line. Expectations from the wider community as well, especially academics in state and private universities towards the KPK, can continue to eradicate corruption in Indonesia to its roots. Thus, giving a heavy effect for the perpetrators who do it. The public and academics are also ready to assist the KPK, in solving problems of forensic linguistic corruption trials in the form of teaching, dedication and research for the purpose of developing science and educating the lives of the Indonesian people.

Acknowledgments. The authors would like to address their deepest appreciation to The Ministry of Research and Community Service, Directorate General of Research and Development Advancement, Ministry of Research, Technology and Higher Education of Indonesia for the funding through the research grant under the PDUPT Research Grant scheme.

\section{References}

[1] MAHKAMAH AGUNG, "Perekaman Proses Persidangan.pdf.” p. 2, 2012. 
[2] Undang-Undang Nomor 30 Tahun 2002. Indonesia, 2002.

[3] D. R. Ladd, Intonational phonology. Amsterdam: John Benjamins Publishing Company, 2010.

[4] A. Cruttenden, Intonation. Second edition. Cambridge: Cambridge University Press, 1997.

[5] I. P. K. Adhi, "Rekaman Elekronik Personal Chat Pada Social Media Sebagai Alat Bukti," Media Iuris, vol. 1, no. 3, p. 457, 2018.

[6] B. Shavers and J. Bair, Hiding Behind the Keyboard: Uncovering Covert Communication Methods with Forensic Analysis. 2016.

[7] W. Y. Shanty, "Analisis Terhadap Fungsi Bahasa Indonesia Hukum Dalam Mewujudkan Kepastian Hukum,” J. Cakrawala Huk., vol. 7, no. 2, pp. 268-280, 2016.

[8] J. Subagja, "Sanksi Pidana Mati terhadap Pelaku Tindak Pidana Korupsi," Universitas Airlangga, Surabaya, 2015.

[9] Syamsudin, "Perbandingan penegakan hukum tindak pidana korupsi di Indonesia dengan China," Universitas Hasanuddin, 2017.

[10] P. W. Kemdikbud, "Badan Bahasa Petakan 652 Bahasa Daerah di Indonesia," 2018.

[11] Ramiyanto, "Bukti Elektronik Sebagai Alat Bukti Yang Sah Dalam Hukum Acara Pidana," J. Huk. dan Peradil., vol. 6, no. 3, p. 463, 2017.

[12] U. Pakaya, "Negara Hukum: Membangun Hukum untuk Keadilan dan Kesejahteraan," Negara Huk., vol. 8, no. 1, pp. 151-175, 2017.

[13] S. Sinha, "Forensic linguistics and forensic phonetics: An introduction," J. Interdiscip. Multidiscip. Res., vol. 2, no. 6, pp. 153-157, 2015.

[14] Y. Kristianto, "Linguistik forensik: Sebuah tinjauan bahasa dalam ranah hukum," Litera J. Bhs. dan Sastra, vol. 1, no. 1, pp. 97-102, 2015.

[15] Yani Suryani and Nani Darmayanti, "Kemahiran Berbahasa Indonesia Penutur Korea : Kajian Prosodi Dengan Pendekatan Fonetik Eksperimental," vol. 4, no. 2, pp. 52-63, 2016.

[16] T. S. Sinar, Nurlela, and T. T. Zein, "Features of Schematic Structure of Courtroom Discourse of Corruption Case," in TALENTA- International Conference on Science and Technology 2019 [TALENTA-ICST2019], 2019.

[17] N. Qamar and H. Djanggih, "Peranan Bahasa Hukum dalam Perumusan Norma Perundang-undangan,” J. Ilm. Kebijak. Huk., vol. 11, no. 3, pp. 337-347, 2017. 